\title{
An Attempt to Assess the Water Quality in the Dunajec River According to the Requirements for Waters as Fish Habitat
}

\section{Introduction}

The monitoring and the control of water quality and water resources make a priority of the Framework Water Directive [1], which pays attention not only at the significance of water for human life and health, water management, industry, but also its significance for the regulation of ecosystems. Systematic water quality control allows for noticing unfavourable environmental changes in time. The aim of studies on water quality is to make basis for decisions on actions to improve the state of waters and protect them from pollution [2].

The requirement to examine and assess the quality of surface waters is also included in the framework of the State Environmental Monitoring, which results from the legal act named the Water Law [3].

\section{The Study Area}

It is very important to control the Dunajec River, considered the most beautiful and most popular mountainous Polish river [4]. It flows through South Poland, surrounded by picturesque mountainous scenery, where the landscape changes constantly. The springs of the Dunajec are in the West Tatra at 1,540 m a.s.1., on the slopes of the main gorge of the West Tatra. The Dunajec, on its full length of $247.1 \mathrm{~km}$ goes through the Pieniny Mountains, Beskid Sądecki, Kotlina Sądecka, Pogórze Rożnowskie and the Vistula Lowland. It makes numerous meanders and ends up in the Vistula River. The area of the catchment is $6,804 \mathrm{~km}^{2}$, making (together with the San River) the most important Carpathian right-bank tributary of the Vistula River.

* AGH University of Science and Technology, Faculty Energy and Fuels, Krakow, Poland

** AGH University of Science and Technology, Faculty of Mining Surveying and Environmental Engineering, Krakow, Poland

*** Gruca Marchacz office of Geodesy, Nowy Sącz 
The Dunajec River also makes a habitat for many organisms, including many species of fish, which makes it a good place for amateur recreational angling. By taking care about the living conditions and environment for fish we take care about the health of consumers. Thus, the monitoring of rivers is so important [5].

The studies of the Dunajec River and its tributaries confirmed the occurrence of at least 26 species of fish representing nine families [6]:

1) cyprinid (Cyprinidae) - 15 species: the asp Aspius aspius (L.), the barbel Barbus barbus (L.) and Barbus peloponnesius Valenciennes, the vimba breamVimba vimba (L.), the ide Leuciscus idus (L.), the common dace Leuciscus leuciscus (L.), the Prussian carp Carassius gibelio (Bloch), the gudgeon Gobio gobio (L.), the European chub Squalius cephalus (L.), the silver bream Blicca bioerkna (L.), the common bream Abramis brama (L.), the spirlin Alburnoides bipunctatus (Bloch), the common roach Rutilus rutilus (L.), the common nase Chondrostoma nasus (L.), the common bleak Alburnus alburnus (L.);

2) salmonid (Salmonidae) - two species: the brown trout Salmo trutta morpha fario L. and the huchen Hucho hucho (L.);

3) Percidae - tree species: the European perch Perca fluviatilis L., the zander Sander lucioperca (L.), the ruffe Gymnocephalus cernuus (L.);

4) Lotidae - one species: the burbot Lota lota (L.);

5) Cottidae - one species: the bullhead Cottus gobio L.;

6) Balitoridae - one species: the stone loach, Barbatula barbatula (L.);

7) Thymallinae - one species: the grayling Thymallus thymallus (L.);

8) Esocidae - one species: the northern pike Esox lucius L.;

9) Anguillidae - one species: the European eel, Anguilla anguilla (L.).

In the area of Małopolska, under the supervision of the Provincial Inspectorate of Environmental Protection (WIOŚ) in Krakow, the quality of surface waters is examined according to the "Programme of the State Environmental Monitoring". This programme covers the analyses and assessment of the quality of water and water sediments of rivers, lakes and reservoirs including the Dunajec River. The monitoring was carried out by the Delegators in Nowy Sącz [7]. The information on surface waters provided by monitoring is used in the planning and management of water resources and the assessment of the progress in reaching environmental purposes. All the actions are aimed at achieving good ecological state by 2015 [8].

\section{Monitoring Methods}

The studies were mainly aimed at:

- general water quality assessment according to the classes,

- assessment of the degree of eutrophication of surface waters,

- assessment of the water quality according to the criteria of their usefulness in water supply, the categories for drinking waters,

- the assessment of water quality in terms of habitat for fish. 
Depending on the established for each place research programme, the studies include an analysis of variability in achieving the required standards of physical, chemical biological and microbiological parameters marked in the uniform part of the waters [8].

Following the regulations adjusting the Polish law to the requirements of the Framework Water Directive [1,9] the monitoring of surface waters is carried out in the following areas:

- diagnostic monitoring,

- operational monitoring,

- research monitoring.

The Provincial Inspectorate of Environmental Protection in Krakow, Delegators of Nowy Sacz have a network of measurement points, including three measurement points on the river, located in the following localities:

- 1 pt $\rightarrow$ Kurów - km 98.0,

- $2 \mathrm{pt} \rightarrow$ Świniarsko - km 110.8,

- 3 pt $\rightarrow$ Czerwony Klasztor - km 163.8.

The first stage and important link in the water quality monitoring is sampling. The correctness of the sampling conditions correct results of analyses and the results reflecting real concentration of chemical compounds in water and its purity status. The samples should represent the whole volume of the medium.

There are three main purposes of water sampling:

1) quality control to make decisions (short-time corrections),

2) analyses characterizing their quality (long-term trends),

3) analyses trying to identify sources of pollution.

Studies on the Dunajec River are carried out in each point with the frequency of sampling 12 times a year, i.e. every month. Monthly sampling will include 53 quality indexes of water, including the contained in the Enclosure to the Enactment of the Minister of Environment on physical and chemical indexes referring to the requirements for inland waters as the fish environment in natural conditions $[8,10,11]$ as well as the requirements for drinking water [12]. Then, the properly collected and protected water sample is transported by the staff of WIOS to the laboratory, where water quality analyses are carried out by specialists of the respective laboratory divisions. Moreover, in the measurement check point of Świniarsko additional analyses are carried out, allowing the definition of the water quality categories according to the Enactment of the Minister of Environment on the requirements that should be fulfilled for the surface waters used in drinking water supply.

\section{The Experimental Part}

Apart from the analysis of the data from WIOSŚ, the analyses of water samples of the Dunajec River were carried out by the authors to analyse several important parameters in terms of living conditions for fish in the Dunajec River. The 
measurement lasted nine months, within that time eight sampling and analysis series were carried out so that two series cover one season and the seasonal comparison of changes could be possible.

The subsequent sampling and analysis series were carried out on the following days:

- 03/09/2010 and 06/09/2010,

- 07/01/2010 and 10/01/2010,

- 13/04/2011 and 26/04/2011,

- 20/06/2011 and 22/06/2011.

For the analyses the Tetra test $6 \mathrm{w} 1$ and classical potentiometric techniques were applied. The test allowed, for the measurement of the following water properties:

- general hardness,

- carbonate hardness,

- content of nitrites $\left(\mathrm{NO}_{2}\right)$,

- content of nitrates $\left(\mathrm{NO}_{3}\right)$,

- content of chlorine $\left(\mathrm{Cl}_{2}\right)$,

$-\mathrm{pH}$,

- content of phosphates $\left(\mathrm{PO}_{4}\right)$.

The test contains two ranges of measurement: $0.01-1 \mathrm{ppm}$ and $0.03-3 \mathrm{ppm}$. The whole content allows 60 analyses.

The water was taken according to the Polish Standard [13]. The water was taken in a horizontal profile on the depth of about $20-50 \mathrm{~cm}$ below the tract. If the river was shallower than $50 \mathrm{~cm}$, the sampling point was on about $1 / 3$ of the depth. Immediately after sampling the analyses were done. The first stage was the measurement of water temperature. The temperature was measured by a thermometer on the depth of sampling; waiting 10 to make the measurement reliable. The results of the analyses were written into the tables.

Then, with the straps of test 6 in 1, general hardness, carbonate hardness, nitrite content $\left(\mathrm{NO}_{2}\right)$, nitrate content $\left(\mathrm{NO}_{3}\right)$, chlorine content $\left(\mathrm{Cl}_{2}\right)$ and $\mathrm{pH}$ were measured in the following way:

1. The strap was taken out the tube, then the tube was closed.

2. The strap was immersed in the water for several seconds.

3. The strap in the water was moved tree times.

4. The strap was removed and shaken to remove the excess of water.

5. The chlorine test field was compared to the scale of colours immediately.

6. After about 60 seconds the remaining test fields were compared to the scale of colours.

7. The water sampling and analyses were repeated.

8. The mean value of the indexes was calculated.

9. The results were put in the tables of results. 
With the reagents of the Profi Test Phosphate phosphates in water were measured:

1. With the provided syringe $10 \mathrm{ml}$ of tested water were taken.

2. To the tested water 4 drops of $\mathrm{PO}_{4}$ reagent no. 1 were added.

3. The test tube was closed and was being shaken for 10 seconds.

4. A pinch (on a small spoon) of $\mathrm{PO}_{4}$ reagent no. 2 was added.

5. The content was mixed for 30 seconds.

6. The open test tube was compared to the table of border values.

7. The values were read and written in the documentation.

Additionally the colour of water was measured in the following way:

The water sample was put into a clean transparent colourless bottle, if the residue was present, it was necessary to wait until it sediments on the bottom. Then the colour was assessed visually in a natural white light. As a result the shade and intensity of colours were given. This way a superficial colour assessment was made. As a reference method verifying the value of all the obtained results, the analyses with potentiometric techniques were carried out in a licensed chemical laboratory.

\section{The Statistical Analysis of the Results}

The results of the statistic analysis of the samples taken and analysed by the authors are shown in Tables 1-4.

Table 1. Results of the statistic analysis of the water purity indexes,

Dunajec - September 2010

\begin{tabular}{|c|c|c|c|c|c|c||}
\hline Parameter & Unit & Min & Max & Mean & Median & Standard deviation \\
\hline \hline Water temperature & ${ }^{\circ} \mathrm{C}$ & 10.00 & 13.50 & 11.28 & 11.10 & 1.44 \\
\hline Reaction & $\mathrm{pH}$ & 8.00 & 8.40 & 8.20 & 8.20 & 0.22 \\
\hline Colour & - & 10.00 & 20.00 & 15.00 & 15.00 & 4.47 \\
\hline Nitrate & $\mathrm{mg} / \mathrm{dm}^{3}$ & 5.00 & 5.00 & 5.00 & 5.00 & 0.00 \\
\hline Nitrite & $\mathrm{mg} / \mathrm{dm}^{3}$ & 0.00 & 0.50 & 0.21 & 0.13 & 0.25 \\
\hline Chlorine & $\mathrm{mg} / \mathrm{dm}^{3}$ & 1.50 & 3.00 & 2.50 & 3.00 & 0.77 \\
\hline General hardness & $\mathrm{dH}$ & 8.00 & 16.00 & 13.60 & 16.00 & 3.58 \\
\hline Carbonate hardness & $\mathrm{dH}$ & 10.00 & 20.00 & 14.17 & 15.00 & 3.76 \\
\hline $\mathrm{PO}_{4}$ & $\mathrm{mg} / \mathrm{dm}^{3}$ & 0.08 & 0.25 & 0.17 & 0.17 & 0.07 \\
\hline
\end{tabular}


Table 2. Results of the statistical analysis of the water purity indexes, Dunajec - winter 2010

\begin{tabular}{||c|c|c|c|c|c|c||}
\hline Parameter & Unit & Min & Max & Mean & Median & Standard deviation \\
\hline \hline Water temperature & ${ }^{\circ} \mathrm{C}$ & 1.00 & 2.50 & 1.92 & 2.00 & 0.58 \\
\hline Reaction & $\mathrm{pH}$ & 8.00 & 10.00 & 8.97 & 8.70 & 0.86 \\
\hline Colour & - & 7.60 & 10.00 & 8.93 & 9.20 & 1.20 \\
\hline Nitrate & $\mathrm{mg} / \mathrm{dm}^{3}$ & 5.00 & 25.00 & 10.83 & 10.00 & 7.36 \\
\hline Nitrite & $\mathrm{mg} / \mathrm{dm}^{3}$ & 0.00 & 0.50 & 0.17 & 0.00 & 0.26 \\
\hline Chlorine & $\mathrm{mg} / \mathrm{dm}^{3}$ & 1.50 & 2.00 & 1.58 & 1.50 & 0.20 \\
\hline General hardness & $\mathrm{dH}$ & 8.00 & 16.00 & 13.33 & 16.00 & 4.13 \\
\hline Carbonate hardness & $\mathrm{dH}$ & 10.00 & 20.00 & 13.33 & 12.50 & 4.08 \\
\hline $\mathrm{PO}_{4}$ & $\mathrm{mg} / \mathrm{dm}^{3}$ & 0.08 & 0.17 & 0.14 & 0.17 & 0.05 \\
\hline
\end{tabular}

Table 3. Results of the statistical analysis of the water purity indexes, Dunajec - spring 2011

\begin{tabular}{||c|c|c|c|c|c|c||}
\hline Parameter & Unit & Min & Max & Mean & Median & Standard deviation \\
\hline \hline Water temperature & ${ }^{\circ} \mathrm{C}$ & 7.5 & 13.00 & 10.08 & 10.50 & 3.30 \\
\hline Reaction & $\mathrm{pH}$ & 7.6 & 8.40 & 8.07 & 8.00 & 2.70 \\
\hline Colour & - & 5.0 & 5.00 & 5.00 & 5.00 & 1.45 \\
\hline Nitrate & $\mathrm{mg} / \mathrm{dm}^{3}$ & 5.0 & 10.00 & 7.50 & 7.50 & 2.91 \\
\hline Nitrite & $\mathrm{mg} / \mathrm{dm}^{3}$ & 0.0 & 0.50 & 0.25 & 0.25 & 0.97 \\
\hline Chlorine & $\mathrm{mg} / \mathrm{dm}^{3}$ & 1.5 & 3.00 & 2.50 & 3.00 & 1.16 \\
\hline General hardness & $\mathrm{dH}$ & 8.0 & 16.00 & 14.40 & 16.00 & 3.58 \\
\hline Carbonate hardness & $\mathrm{dH}$ & 10.0 & 15.00 & 12.50 & 12.50 & 2.74 \\
\hline $\mathrm{PO}_{4}$ & $\mathrm{mg} / \mathrm{dm}^{3}$ & 0.1 & 0.33 & 0.22 & 0.25 & 0.08 \\
\hline
\end{tabular}

Table 4. Results of the statistical analysis of the water purity indexes, Dunajec - June 2011

\begin{tabular}{||c|c|c|c|c|c|c||}
\hline Parameter & Unit & Min & Max & Mean & Median & Standard deviation \\
\hline \hline Water temperature & ${ }^{\circ} \mathrm{C}$ & 18.00 & 20.00 & 19.02 & 19.05 & 0.71 \\
\hline Reaction & $\mathrm{pH}$ & 7.20 & 8.40 & 7.67 & 7.60 & 0.47 \\
\hline Colour & - & 5.00 & 5.00 & 5.00 & 5.00 & 0.00 \\
\hline Nitrate & $\mathrm{mg} / \mathrm{dm}^{3}$ & 10.00 & 25.00 & 15.00 & 10.00 & 7.75 \\
\hline Nitrite & $\mathrm{mg} / \mathrm{dm}^{3}$ & 0.00 & 0.50 & 0.25 & 0.25 & 0.27 \\
\hline Chlorine & $\mathrm{mg} / \mathrm{dm}^{3}$ & 0.80 & 3.00 & 1.77 & 1.50 & 1.01 \\
\hline General hardness & $\mathrm{dH}$ & 8.00 & 16.00 & 10.00 & 8.00 & 3.35 \\
\hline Carbonate hardness & $\mathrm{dH}$ & 10.00 & 15.00 & 11.67 & 10.00 & 2.58 \\
\hline $\mathrm{PO}_{4}$ & $\mathrm{mg} / \mathrm{dm}^{3}$ & 0.017 & 0.17 & 0.10 & 0.10 & 0.05 \\
\hline
\end{tabular}




\section{Discussion and Conclusions}

The assessment of the waters as fish habitat in natural conditions is carried out by comparing the values of pollution indexes with the accepted values defined in the Enactment of the Minister of Environment of $4^{\text {th }}$ October 2002 [10]. The index or group of indexes transgressing maximum acceptable values are decisive in the classification of waters. The results are shown in Tables 5 and 6.

Table 5. The assessment of the usefulness the Dunajec waters for fish, 2005-2010 according to the studies of the Voivodeship Inspectorate of Environmental Protection (WiOŚ)

\begin{tabular}{|c|c|c|c|c|}
\hline Year & No. & $\begin{array}{l}\text { Measurement } \\
\text { point }\end{array}$ & Usefulness of water for fish & Water degrading indexes \\
\hline \multirow[t]{3}{*}{2005} & 1 & Kurów & does not fulfil the requirements & $\begin{array}{l}\text { general residue, BZT5, nitrites, } \\
\text { ammonium nitrogen }\end{array}$ \\
\hline & 2 & Świniarsko & does not fulfil the requirements & general residue, nitrites \\
\hline & 3 & $\begin{array}{l}\text { Czerwony } \\
\text { Klasztor }\end{array}$ & Cyprinidae & general residue, nitrites \\
\hline \multirow[t]{3}{*}{2006} & 1 & Kurów & does not fulfil the requirements & $\begin{array}{l}\text { general residue, BZT5, nitrites, } \\
\text { ammonium nitrogen }\end{array}$ \\
\hline & 2 & Świniarsko & Cyprinidae & $\begin{array}{l}\text { general residue, nitrites, } \\
\text { ammonium nitrogen }\end{array}$ \\
\hline & 3 & $\begin{array}{l}\text { Czerwony } \\
\text { Klasztor }\end{array}$ & Salmonidae & \\
\hline \multirow[t]{3}{*}{2007} & 1 & Kurów & does not fulfil the requirements & $\begin{array}{l}\text { general residue, ammonium } \\
\text { nitrogen }\end{array}$ \\
\hline & 2 & Świniarsko & does not fulfil the requirements & $\begin{array}{l}\text { general residue, nitrites, } \\
\text { ammonium nitrogen }\end{array}$ \\
\hline & 3 & $\begin{array}{l}\text { Czerwony } \\
\text { Klasztor }\end{array}$ & Cyprinidae & nitrites \\
\hline \multirow[t]{3}{*}{2008} & 1 & Kurów & does not fulfil the requirements & general residue, $\mathrm{BZT}_{5}$, nitrites \\
\hline & 2 & Świniarsko & does not fulfil the requirements & $\mathrm{BZT}_{5}$, total phosphorus, nitrites \\
\hline & 3 & $\begin{array}{l}\text { Czerwony } \\
\text { Klasztor }\end{array}$ & Cyprinidae & nitrites \\
\hline \multirow[t]{3}{*}{2009} & 1 & Kurów & does not fulfil the requirements & $\mathrm{BZT}_{5}$, nitrites \\
\hline & 2 & Świniarsko & does not fulfil the requirements & $\mathrm{BZT}_{5}$, nitrites \\
\hline & 3 & $\begin{array}{l}\text { Czerwony } \\
\text { Klasztor }\end{array}$ & Cyprinidae & nitrites \\
\hline \multirow[t]{3}{*}{2010} & 1 & Kurów & does not fulfil the requirements & general residue, $\mathrm{BZT}_{5}$, nitrites \\
\hline & 2 & Świniarsko & does not fulfil the requirements & general residue, $\mathrm{BZT}_{5}$, nitrites \\
\hline & 3 & $\begin{array}{l}\text { Czerwony } \\
\text { Klasztor }\end{array}$ & does not fulfil the requirements & nitrites \\
\hline
\end{tabular}


Table 6. The assessment of the usefulness of the Dunajec water for fish, depending on season, according to the authors' analyses

\begin{tabular}{||c|c|c|c|}
\hline \hline Season & $\begin{array}{c}\text { Measurement check } \\
\text { points }\end{array}$ & Usefulness of water for fish & Indexes degrading water \\
\hline \hline September & $\begin{array}{c}\text { Kurów } \\
\text { Swiniarsko } \\
\text { Czerwony Klasztor }\end{array}$ & $\begin{array}{c}\text { does not fulfil the } \\
\text { requirements }\end{array}$ & nitrites \\
\cline { 1 - 3 } & \multirow{2}{*}{ June } & $\begin{array}{c}\text { does not fulfil the } \\
\text { requirements }\end{array}$ & $\begin{array}{c}\text { nitrites, } \\
\text { total phosphorus }\end{array}$ \\
\cline { 4 - 5 } January & & $\begin{array}{c}\text { does not fulfil the } \\
\text { requirements }\end{array}$ & nitrites \\
\cline { 3 - 4 } & & $\begin{array}{c}\text { does not fulfil the } \\
\text { requirements }\end{array}$ & nitrites \\
\hline
\end{tabular}

Analysing the obtained mean values of temperatures we notice that in none of the studied points, transgressions in temperature were noticed. In the spring in all of the points the temperature ranged between $7.5^{\circ} \mathrm{C}$ and $13^{\circ} \mathrm{C}$, in summer: $18-20^{\circ} \mathrm{C}$, in autumn: $10-13.5^{\circ} \mathrm{C}$ and in winter: $1-2.5^{\circ} \mathrm{C}$. The $\mathrm{pH}$ of natural water ranged from 4 to 9 , however most waters had $\mathrm{pH}$ 6.5-8.5. It is recommended that the $\mathrm{pH}$ of water for fish is 6-9. The obtained mean results of $\mathrm{pH}$ are the following: autumn 8.2 , winter 9 , spring 8 , summer 7.7 , which puts them within the acceptable limits for fish. The level of nitrites in the Dunajec is significantly transgressed in any season. According to the enclosure to the enactment [10] their amount for salmonid fish should not exceed $0.01 \mathrm{mg} / \mathrm{dm}^{3}$ and for cyprinids $0.03 \mathrm{mg} / \mathrm{dm}^{3}$; while in the Dunajec it exceeds these values several times, posing threat for fish. The amount of phosphates in active surface waters is small. The acceptable amount of phosphates for fish in waters should not exceed $0.2 \mathrm{mg} / \mathrm{dm}^{3}$ for salmonids and $0.4 \mathrm{mg} / \mathrm{dm}^{3}$ for cyprinids. Analysing the obtained results we can see that in the spring the maximum accepted level is exceeded.

The results by WIOŚ present mean values of different indicators from 2005-2010, while in the experimental part the water was examined in the subsequent seasons of 2010/2011. Before 2010 the Dunajec made an adequate environment for fish. In Czerwony Klasztor the requirements for salmonids were fulfilled. In 2006 in Świniarsko it was adequate for cyprinids. In other measurement check points the studies revealed that the water was not suitable for salmonid or even cyprinid fish. It is disturbing to see the whole-year or seasonal analysis in 2010/2011 proving that the water does not fulfil the requirements for fish habitat. The main factor degrading water were nitrites. Nitrites can get to surface waters from municipal wastewaters, transport wastes, industrial wastewaters and fields fertilized with artificial nitric fertilizers. Although the water analyses showed an excessive level of pollutants, compared to the acceptable values for fish, the interviews with the anglers (P. Ciagło - unpublished) as well as the analysis of the angler's reports (A. Wagner, B. Patuła, R. Mazur, J. Mazur - unpublished) showed 
that in the Dunajec River the following fish occur: the brown trout Salmo trutta morpha fario, rainbow trout Oncorhynchus mykiss Walbaum, bream Abramis brama, pike Esox lucius, bullhead Cottus gobio, European chub Squalius cephalus, ide Leuciscus idus, European perch Perca fluviatilis, common nase Chondrostoma nasus, barbel Barbus barbus, grayling Thymallus thymallus. This contradiction can result from the fact that the control points are not the same as the places of angling, moreover the averaged values can be much higher than the values present for the most of the time, because the high values in certain short periods increase the averaged results. The results show that certain indexes increase, others decrease; it must be remembered, however that the water quality control of rivers is very important and until achieving a good ecological status the monitoring should be carried out constantly [11].

\section{References}

[1] Directive 2000/60/EC of the European Parliament and of the Council of 23 October 2000 establishing a framework for Community action in the field of water policy. Official Journal of the European Communities L 327/1, [on-line:]: http://eurlex.europa.eu/LexUriServ/LexUriServ.do?uri=CELEX:32000L0060:EN:NOT [access: 8 July 2011].

[2] Program ochrony środowiska dla powiatu nowosadeckiego na lata 20042011. Nowy Sącz 2004, [on-line:] http://www.wrotamalopolski.pl/NR/ rdonlyres/8722DDC6-1CB8-49A4-971B-2A5166AA77A5/197402/POS_nowosadecki_pouchwaleniu.pdf [access: 8 July 2011].

[3] Ustawa z dnia 18 lipca 2001 r. - Prawo wodne. Dz. U. 2005, nr 239, poz. 2019 z późn. zm.

[4] Leśniak J., Leśniak A.: Encyklopedia sadecka, Nowy Sącz 2000.

[5] Michałowicz-Kubal M., Kubal G.: Powiat nowosadecki. Apla, Krosno 2000.

[6] Augustyn L. (red.): Ichtiofauna dorzecza Dunajca na początku XXI wieku. PWSZ, Nowy Sącz 2006.

[7] Kiryk F. (red.): Dzieje miasta Nowego Sacza. Tom 1. Wydawnictwo Naukowe PWN, Warszawa, Kraków 1992.

[8] Problemy Zagospodarowania Ziem Górskich, z. 21 [red. Stanisław Kopeć]. Państwowe Wydawnictwo Naukowe, Kraków 1981.

[9] Encyklopedia RDW - Ramowa Dyrektywa Wodna. [on-line:] http://www.rdw. org.pl/encyklopedia-rdw/m.html [access: 10 July 2011].

[10] Rozporzadzenie Ministra Środowiska z dnia 4 października 2002 r. w sprawie wymagań, jakim powinny odpowiadać wody śródladowe będace środowiskiem życia ryb w warunkach naturalnych. Dz. U. 2002, nr 176, poz. 1455.

[11] Chełmicki W.: Woda: zasoby, degradacja, ochrona. Wydawnictwo Naukowe PWN, Warszawa 2001. 
[12] Rozporzadzenie Ministra Środowiska z dnia 27 listopada 2002 r. w sprawie wymagań, jakim powinny odpowiadać wody powierzchniowe wykorzystywane do zaopatrzenia ludności w wode przeznaczona do spożycia: Dz. U. 2002, nr 204, poz. 1728.

[13] PN-EN ISO 5667-1:2008: Jakość wody. Pobieranie próbek. Część 1: Wytyczne dotyczace opracowywania programów pobierania próbek $i$ technik pobierania próbek. 